\title{
The estimation of the digestibility and metabolizable energy content of ruminant feedingstuffs from the gas production when they are incubated with rumen liquor in vitro
}

\author{
BY K. H. MENKE, L. RAAB, A. SALEWSKI,* H. STEINGASS, \\ D. FRITZ AND W. SCHNEIDER \\ Institute for Animal Nutrition, University of Hohenheim, West Germany
}

(Revised MS. received 8 March 1979)

\begin{abstract}
SUMMARY
A rapid method for measuring gas production during incubation of feedingstuffs with rumen liquor in vitro is described. Gas production in $24 \mathrm{~h}$ from $200 \mathrm{mg}$ feed dry matter was well correlated with digestibility of organic matter, determined in vivo with sheep. Multiple regression analysis, when it included data from proximate analysis, resulted in an equation $(R=0.98)$ for prediction of metabolizable energy content, based on 30 experiments with rations varying in protein and crude fibre content, and 59 other experiments with concentrates. Energy content was in the range of 7.7-13.2 MJ ME $/ \mathrm{kg}$ D.M. $(\bar{x} \pm$ S.D. $=11 \cdot 17 \pm 1 \cdot 08)$. The residual standard deviation of the equation was 0.25 MJ. Gas production was measured in calibrated syringes. The only chemical determinations needed are dry matter, protein and fat. Differences in activity between batches of rumen liquor are corrected by reference to gas production with standard feedingstuffs (hay meal and maize starch).
\end{abstract}

\section{INTRODUCTION}

In vitro techniques promise to become an important tool for the evaluation of ruminant feeds. However, the methods presently available are still time consuming and not precise. The investigations of Tilley \& Terry (1963) mark an important step in this field. Use of the determination of neutraldetergent fibre (Goering \& Van Soest, 1970) in place of the treatment with enzymes reduces the time required by about $30 \%$, but has no advantage in reproducibility and precision when compared with in vivo experiments.

In previous experiments designed to study the stoichiometry of rumen fermentation (Menke \& Ehrensvärd, 1974) we used a syringe-type closed system and observed a nearly constant rate of gas production $\left(\mathrm{CO}_{2}\right.$ and $\left.\mathrm{CH}_{1}\right)$ when the same substrate was given in the same amounts. Later experiments with feedingstuffs of different digestibilities showed marked differences in the amount of gas produced in $24 \mathrm{~h}$, being about $20 \mathrm{ml}$ with $200 \mathrm{mg}$ ground wood but as much as $70 \mathrm{ml}$ with the same weight of feedingstuffs high in digestible carbohydrates. The method derived from these observations has

* Present address: Landwirtschaftskammer Rheinland, Endenicher Allee, 53 Bonn, Federal Republic of Germany. now been tested in $\mathbf{8 9}$ digestibility trials with sheep and standardized with hay meal and maize starch. The results permit the method to be recommended for routine application.

\section{MATERIALS AND METHODS}

Fermentation was carried out in glass-syringes (piston-pipettes) of $32 \mathrm{~mm}$ internal diameter and about $200 \mathrm{~mm}$ in length with a volume of $150 \mathrm{ml}$, $100 \mathrm{ml}$ of which were calibrated. The piston fitted precisely and was lubricated using a little Vaseline. The 'needle' of the syringe was connected with a silicon rubber tube of 4-5 cm length, closed by a plastic clip (Fig. 1).

The sample (200 $\mathrm{mg}$ dry matter) first was introduced in to the syringe. The material was not finely ground because of observed differences in digestibility (in vivo) and gas production (in vitro) between coarse and fine ground roughages. The difference in gas production between ground and cut hay was $4-5 \mathrm{ml}$ in $24 \mathrm{~h}$. Therefore roughages were chopped by a slow rotating meat cutter, which gave material of up to $2 \mathrm{~mm}$ length, pellets were broken in a mortar, and meals were used without any further treatment. The feedingstuff was incubated in tripli. cates on at least two different days, yielding six parallel measurements. The rumen liquor was 

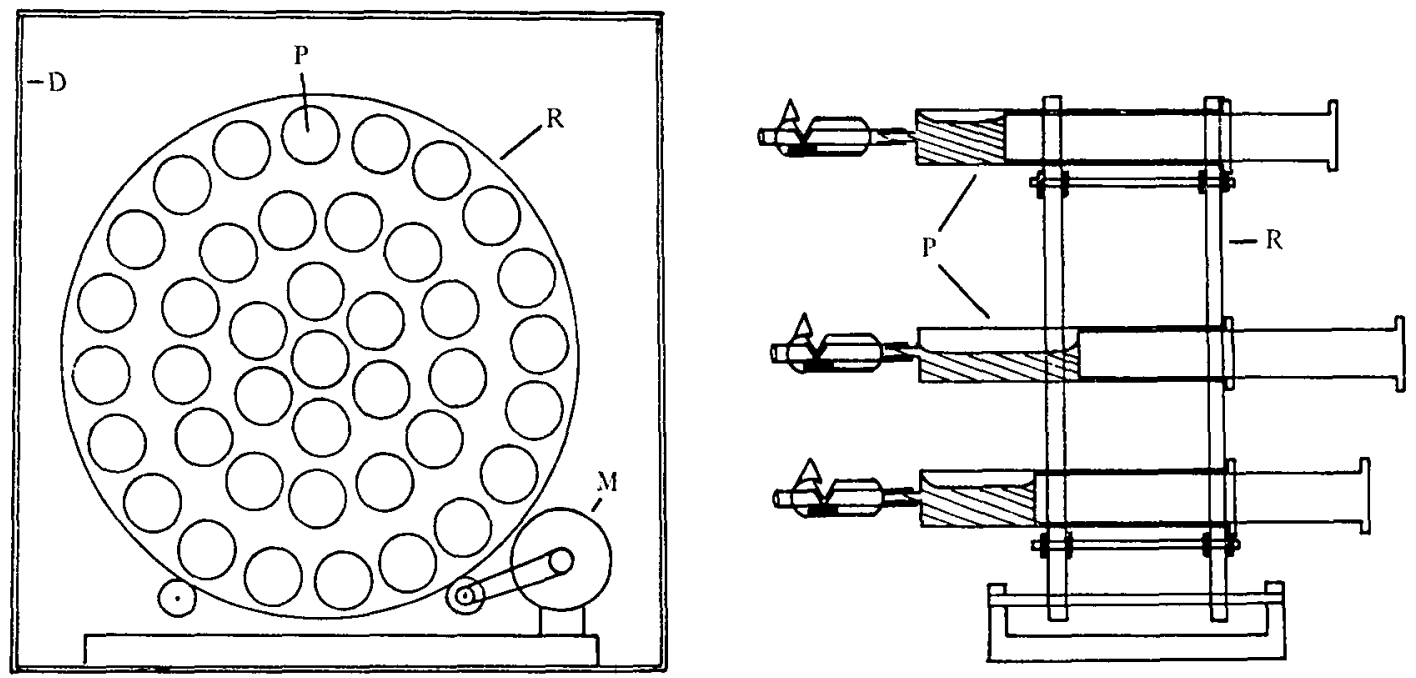

Fig. 1. Piston-syringes (P) in a rotor $(R)$, moved by an electric motor $(M)$ in a drying oven (D) at $39 \pm 0.5^{\circ} \mathrm{C}$.

sucked from a rumen-fistulated cow through two layers of cheese cloth into a warm flask of about 21 volume filled with $\mathrm{CO}_{2}$. Rumen liquor was taken before feeding the high roughage ration.

One part of liquor was mixed with two parts of a medium consisting of (added in order) $400 \mathrm{ml}$ $\mathrm{H}_{2} \mathrm{O}, 0.1 \mathrm{ml}$ solution $\mathrm{A}\left(13.2 \mathrm{~g} \mathrm{CaCl} .2 \mathrm{H}_{2} \mathrm{O}, 10.0 \mathrm{~g}\right.$ $\mathrm{MnCl}_{2} .4 \mathrm{H}_{2} \mathrm{O}, 1.0 \mathrm{~g} \mathrm{CoCl}_{2} .6 \mathrm{H}_{2} \mathrm{O}, 8.0 \mathrm{~g} \mathrm{FeCl}_{3} \cdot 6 \mathrm{H}_{2} \mathrm{O}$ and made up to $100 \mathrm{ml}$ with $\mathrm{H}_{2} \mathrm{O}$ ), $200 \mathrm{ml}$ solution $\mathrm{B}$ (39 $\left.\mathrm{g} \mathrm{NaHC} / 1 \mathrm{H}_{2} \mathrm{O}\right), 200 \mathrm{ml}$ solution $\mathrm{C}(5.7 \mathrm{~g}$ $\mathrm{Na}_{2} \mathrm{HPO}_{4}, 6.2 \mathrm{~g} \mathrm{KH}_{2} \mathrm{PO}_{4}, 0.6 \mathrm{~g} \mathrm{MgSO}_{4} .7 \mathrm{H}_{2} \mathrm{O}$ and made up to $1000 \mathrm{ml}$ with $\mathrm{H}_{2} \mathrm{O}$ ), $1 \mathrm{ml}$ resazurine $(0.1 \%, \mathrm{w} / \mathrm{v})$ and $40 \mathrm{ml}$ reduction solution $(95 \mathrm{ml}$ $\mathrm{H}_{2} \mathrm{O}, 4 \mathrm{ml} 1 \mathrm{~N} \cdot \mathrm{NaOH}$ and $625 \mathrm{mg} \mathrm{Na}_{2} \mathrm{~S} \cdot 9 \mathrm{H}_{2} \mathrm{O}$ ). The mixture was kept under $\mathrm{CO}_{2}$ in a water bath at $39{ }^{\circ} \mathrm{C}$ and stirred by a magnetic stirrer.

Thirty $\mathrm{ml}$ of the rumen liquor medium-mixture was pipetted with an automatic pump into each syringe prewarmed to $39^{\circ} \mathrm{C}$. Any gas bubbles in the syringe were removed, the plastic clip on the silicon tube closed, the position of the piston read and recorded, and the syringe placed in the incubation apparatus (Fig. 1). The apparatus contains a rotor which consists of two parallel disks of $50 \mathrm{~cm}$ diameter with 60 holes for horizontal location of the syringes. The rotor stands on two axles, one of which is moved by an electric motor, in a ventilated drying oven at $39 \pm 0.5^{\circ} \mathrm{C}$. One rotation per minute was sufficient for continuous mixing of the contents.

All incubations were started in the morning, and 6-8 $\mathrm{h}$ later the position of the piston was read again. If gas production exceeded $60 \mathrm{ml}$ the clip was opened and the piston moved back to the $30 \mathrm{ml}$ position. The final reading was taken $24 \mathrm{~h}$ after the incubation commenced. All readings were taken quickly to avoid a change in temperature; if the readings cannot be taken by two persons simultaneously, it is recommended that the syringes be placed in a water bath at $39^{\circ} \mathrm{C}$ before reading.

Differences in composition and activity of the rumen liquor are controlled by three parallel measurements (in triplicate): (1) rumen liquor + medium mixture without substrate (blank, $G b_{0}$ ); (2) incubation of a standard hay meal ( $200 \mathrm{mg}$ D.M.) which in 13 consecutive experiments yielded a net gas production of $44 \cdot 16 \pm 1.98 \mathrm{ml} / 24 \mathrm{~h}\left(G b_{H}\right)$; and (3) incubation of $140 \mathrm{mg}$ standard hay meal and $60 \mathrm{mg}$ maize starch D.M. which in the same experiments gave measurements of $59 \cdot 80 \pm 1.61 \mathrm{ml} /$ $24 \mathrm{~h}\left(G b_{H S}\right)$.

The blank varied between 6 and $12 \mathrm{ml} / 24 \mathrm{~h}$ and was subtracted from every measurement to give the net gas production. The standard value. for the hay meal chosen $(44 \cdot 16)$ was divided by the measured net value for the standard hay $\left(G b_{H}-\right.$ $\left.G b_{0}\right)$ to give the correction factor $F_{H}$. In the same way the correction factor $F_{H S}$ was derived from the standard value for the concentrate mixture $(59 \cdot 80)$, divided by the measured net gas production $\left(G b_{H S}-G b_{0}\right)$. The mean of these two factors $F_{H}$ and $F_{H S}$ was used for correction of the sample measurements; in most cases the difference between $F_{H}$ and $F_{H S}$ was not significant. A difference would indicate a change in the ratio between cellulolytic and amylolytic activity of the rumen liquor. If this occurs the feeding of the animal has to be changed in the desired direction.

The hay meal may serve as a standard for 6-12 months. For renewal of the hay standard two different hay meals can be mixed in different pro. 


\section{Measurement of digestibility and metabolizable energy}

portions and compared with the previous standard, using the same rumen liquor. It is important that the standards are closely matched, since the regression analysis between in vivo and in vitro measurements is based on these standards ' $44 \cdot 16$ ' and ' $59 \cdot 80$ '.

The digestibility trials were conducted with adult sheep $(n=4-5)$ of the Merino and Black Faced type (Württembergisches Merinolandschaf, schwarzköpfiges Fleischschaf) in metabolism cages. Thirty rations consisting of meadow hay, barley, soya-bean meal, rapeseed meal, sunflower meal and/or maize starch in different proportions were tested in the Institute in Hohenheim (Table 1). These rations were used in the same proportions for in vitro measurement of gas production. Ten single feedingstuffs (linseed meal and expeller, palm-kernel oil meal and expeller, coconut oil meal, cocoa shells, maize gluten feed, wheat bran and two different hays) and 49 dairy cattle compounds (19-29\% crude protein, 3-6\% crude fat) were examined together with $40 \%$ hay in the ration in the 'Lehr- und Versuchsanstalt Haus Riswick' near Kleve. The digestion coefficients of these feedingstuffs were calculated according to the difference principle. Consequently the in vitro mensurements of gas production were done with the single feedingstuffs or compounds and not with the total rations.

In addition 12 hay-concentrate rations varying in hay (31-55\%) and protein content $(10-25 \%)$ were tested in respiration experiments with dairy cows $(n=2)$.

\section{RESULTS}

The relationships between in vivo and in vitro measurements were examined in different regression models. The goodness of fit of the equations to the experimental data was tested using the correlation coefficient $(R)$ and the residual standard deviation (R.S.D.) as criteria. In addition the standard errors of the regression coefficients (S.E.) have been calculated (Searle, 1971). The means of the variables and their standard deviations are given in Table 2. All comparisons were made on a dry-matter basis. Gas production $(G b)$ is defined as the total increase in volume $\left(v_{24}-v_{0}\right)$ minus the blank $\left(G b_{0}\right)$, multiplied by the mean of the factors $F_{H}$ and $F_{H S}(\mathrm{ml} / 24 \mathrm{~h})$

$$
G b=\left(v_{24}-v_{0}-G b_{0}\right)\left(F_{H}+F_{H S}\right) / 2 .
$$

Digestible organic matter $(D O, \mathrm{~g} / \mathrm{kg} O M)$ is given by the equation

$$
\begin{aligned}
& D O=7.65( \pm 0.062) G b+353( \pm 0.59) \\
& R=0.82 ; \quad \text { R.s.D. }=37 ; \quad n=89 ;
\end{aligned}
$$

but since gas production reflects more the content of digestible carbohydrats than of protein and fat, a multiple regression analysis including these crude nutrient contents was carried out

$$
\begin{gathered}
D O=13.3( \pm 0.22) G b-0.05( \pm 0.002) G b^{2} \\
+511( \pm 5 \cdot 7) X P \\
+76( \pm 25.0) X L+91 \cdot 2( \pm 0.31) \\
\quad R=0.96 ; \quad \text { R.S.D. }=19 ; \quad n=89
\end{gathered}
$$

\begin{tabular}{|c|c|c|c|c|}
\hline Variable & Symbol & Mean & S.D. & $\overbrace{}^{\text {Range }}$ \\
\hline $\begin{array}{l}\text { ME for ruminants } \\
\text { (MJ } / \mathrm{kg} \mathrm{D.MI.)}\end{array}$ & $M E_{r}$ & $11 \cdot 17$ & 1.08 & $7 \cdot 7-13 \cdot 2$ \\
\hline Gas production (ml/24 h) & $a b$ & $53 \cdot 7$ & $6 \cdot 8$ & $20 \cdot 6-65 \cdot 7$ \\
\hline $\begin{array}{l}\text { Digestible organio } \\
\text { matter (g/kg OM) }\end{array}$ & DO & 764 & 64 & $473-865$ \\
\hline Crude protein (g/g D.M.) & $X P$ & 0.203 & 0.060 & $0.088-0.377$ \\
\hline Crude fat (g/g D.MI.) & $X L$ & 0.035 & 0.014 & $0.011-0.075$ \\
\hline N-free extract (g/g D.M.) & $X X$ & 0.505 & 0.070 & $0.253-0.649$ \\
\hline
\end{tabular}

Table 1. Composition of rations tested in Hohenheim (range in \%)

Experiment no.

$\begin{array}{llccccc}\text { Feedingstuff } & \text { 1-6 } & 7-12 & 13-18 & 19-24 & 25-27 & 28-30 \\ \text { Hay } & 41-73 & 36-86 & 35-87 & 30-79 & 53-56 & 72-100 \\ \text { Barley } & 6-41 & - & - & - & - & - \\ \text { Starch } & 7-35 & 8-44 & 8-43 & 9-35 & 8-28 & 0-28 \\ \text { Soya-bean meal } & - & 4-22 & - & - & - & - \\ \text { Rapeseed meal } & - & - & 5-27 & - & - & - \\ \begin{array}{l}\text { Sunflower maal } \\ \text { Linseed meal }\end{array} & - & - & - & 12-39 & - & -\end{array}$

Table 2. Means and standard deviations for the variables used in regression analysis $(\mathrm{n}=89)$ 
where $X P$ and $X L=$ crude protein and crude fat, respectively (g/g D.M.).

For calculation of metabolizable energy $\left(M E_{r}\right.$; MJ $/ \mathrm{kg}$ D.M.) from digestible nutrients the equation 3.38 of Schiemann et al. (1971) was used

$$
M E_{r}=15 \cdot 2 D P+34 \cdot 2 D L+12 \cdot 8 D F+15 \cdot 9 D X,
$$

where $D P, D L, D F, D X=\mathrm{g}$ digestible crude protein, fat, fibre and $\mathrm{N}$-free extracts/g D.M. of feedingstuff, respectively, measured in digestion trials with sheep.

Multiple regression analysis of the relationship between $M E_{\mathrm{r}}$ and in vitro measurements $(G b, X P$, $X L$ ) resulted in the equation

$$
\begin{aligned}
M E_{\mathrm{r}}=0.145( \pm 0.0004) G b+4.12( \pm 0.285) X P \\
+6.5( \pm 0.63) X P^{2} \\
+20 \cdot 6( \pm 0.34) X L+1.54( \pm 0.004) \\
(\mathrm{MJJ} / \mathrm{kg} ; \mathrm{g} / \mathrm{g}) \\
R=0.98 ; \text { R.S.D. }=0.247 ; n=89
\end{aligned}
$$

(Fig. 2).

The residual standard deviation was reduced to $0.232 \mathrm{MJ}$ by inclusion of the content of $\mathrm{N}$-free extracts $(X X)$

$$
\begin{aligned}
& M E_{r}=0.118( \pm 0.0009) G b+8.72( \pm 0.087) X P+ \\
& 19 \cdot 21( \pm 0.303) X L(6) \\
&+3.38( \pm 0 \cdot 103) X X+0.691( \pm 0.0038 \\
&(M J / \mathrm{kg} ; \mathrm{g} / \mathrm{g}) \\
& R=0.98 ; \quad \text { R.S.D. }=0.232 ; \quad n=89 .
\end{aligned}
$$

\section{DISCUSSION}

An explanation for the high correlation between gas production in vitro and digestibility (and metabolizability) in vivo can probably be found in the fact that this method is not based on a filtration process for separation of 'digested' and 'undigested' material, and in this way differs from nearly all others in vitro techniques. Such a separation may not give the full information on digestibility, partly because some indigestible or less digestible material may pass the filter, and partly because some digestible material may not be extracted from the indigestible fraction on the filter.

The critical points of the gas production method are: (1) the low sample weight, (2) the difficulties in keeping a standard feedingstuff for correction for deviations caused by changes in the activity of the rumen liquor, and (3) that feedingstuffs which show a significantly slower gas production than the majority may have higher digestibilities in vivo than is indicated by the $G b$-method.

The recommendation not to grind the feedingstuff is of course not in accordance with the need for homogeneous sample material. On the other hand the error due to lack of sample homogeneity may not be as high as the error in reading the amount of gas produced. The calibration of the syringe and the adhesion of the piston does not allow readings in steps smaller than $0.5 \mathrm{ml}$. A greater sample weight could be used, but this renders larger syringes necessary, with the same or even greater relative errors in reading the gas produced. We therefore recommend taking more samples instead of increasing the sample weight. On average the standard error of six parallel measurements was $0.6 \mathrm{ml}$. A standard error of more than $1 \mathrm{ml}$ would indicate that this material needs a third or fourth set of measurements.

As yet we have no comparative results on whether hay meal is a better standard feedingstuff than straw meal or pure cellulose for characterizing the cellulolytic ability of the rumen liquor. The amylolytic properties may best be measured by the addition of starch, but here too, comparative investigations are needed. The factor applied for correction of differences in activity of rumen liquor may be different for roughages and concentrates. In these experiments the difference between the roughage and concentrate factors was small, and for this reason only the mean of $F_{H}$ and $F_{H S}$ was used.

In many cases the negative deviations of the in vitro measurements from the in vivo data were associated with differerent time courses of gas production through the $24 \mathrm{~h}$ incubation. Especially hay and rations high in hay, but also palm kernel expeller and palm kernel extraction meal, showed slower increase. In order to be able to treat these differences in a mathematical way, the readings after $1,3,5,7,8$ and $24 \mathrm{~h}$ were taken for regression analysis. The best fit was achieved with square functions, which on average resulted in $R^{2}$ velues of $0.995(0.98-1.00)$. The maximum of these curves in most cases was reached at 19-22 h. Those samples with strong negative deviations showed maxima after more than $24 \mathrm{~h}$. We therefore made mathematical corrections by extrapolating the curves found by regression analysis, and the best fit to the in vivo data was achieved when extrapolation to $26 \mathrm{~h}$ was chosen. The residual standard deviation was then reduced to $0.209 \mathrm{MJ}$ and the relationship became

$$
\begin{aligned}
M E_{r}= & 0.1074( \pm 0.00077) G b+10.6( \pm 0.076) X P \\
& +17.1( \pm 0.29) X L+5.04( \pm 0.086) X X \\
& -0.098( \pm 0.0037) ; \quad(\mathrm{MJ} / \mathrm{kg}, \mathrm{g} / \mathrm{g})(7) \\
& R=0.98 ; \quad \text { R.S.D. }=0.209 ; \quad n=75
\end{aligned}
$$

We then prolonged the incubation time to $26 \mathrm{~h}$, but the expected improvement in correlation predicted from the mathematical correction was not achieved. In fact the feedingstuffs with an early maximum in gas production showed almost the 


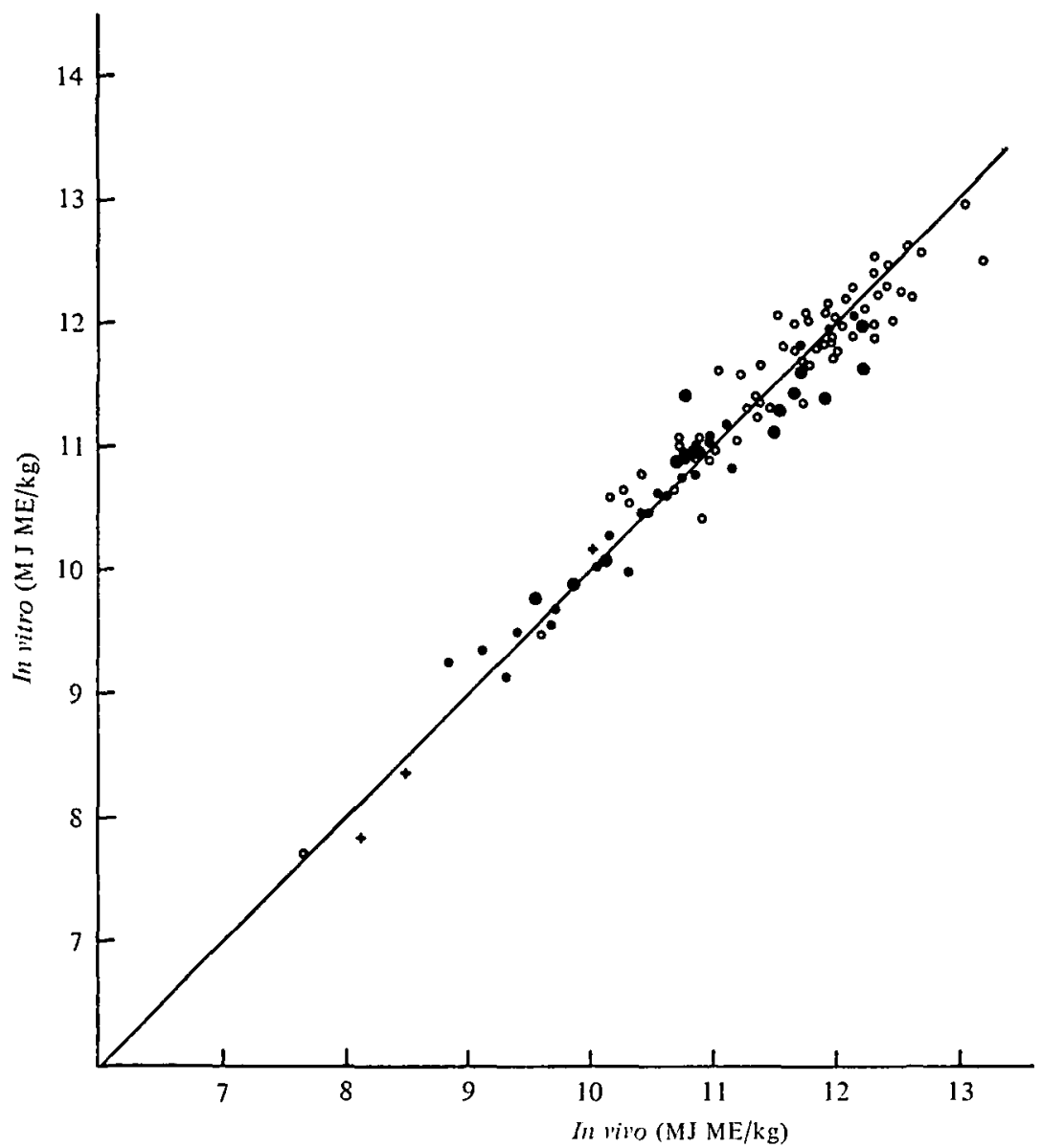

Fig. 2. ME contents derived from in vitro gas production $(G b)$, crude protein $(X P)$ and crude fat $(X L)$, compared with ME contents derived from in vivo digestion experiments using equation (4) or measured in respiration experiments., Rations tested in respiration experiments with cows; $\bullet$, Rations; + , hay; $O$, compounds tested in digestion trials with sheep, and evaluated according to the difference principle (equation 4). The line is drawn from the equation: ME (in vitro) $=0.949 \mathrm{ME}$ (in vivo) $+0.565 ; r^{2}=0.95$.

same increment in the last $2 \mathrm{~h}$ as those with slower increase. The difference between in vivo and in vitro measurements with these feedingstuffs is therefore due either to differences in passage rate and retention time in the rumen, or to better utilization in the small intestine of those nutrients which escape microbial fermentation in the rumen. Incubation for $24 \mathrm{~h}$ may be appropriate for feedingstuffs with average passage rates, but not for those with longer retention times in the rumen, such as hay. It would be worthwhile to investigate these assumptions in detail.

Other possible interfering factors are the atmo. spheric pressure, the $\mathrm{pH}$ of the sample and the content of organic acids in the feedingstuff. In these experiments the variations in atmospheric pressure $(972 \pm 6 \mathrm{MPa})$ had no significant influence on the readings in the $G b$-method. If larger variations occur, it can be expected that they affect the incubations of the standard feedingstuffs to the same extent as the feedingstuffs under investigation. The deviation then is corrected by the factors $F_{H}$ and $F_{H S}$.

The $\mathrm{pH}$ of the sample had no effect as long as the buffer could keep the pH above 6.0. Experiments with fresh forages, especially maize, were in good agreement with equation (5). Details will be published as soon as more experiments with forages, including silages, have been carried out. In silages the organic acids content may cause deviations due to the fact that its ME content is higher than indicated by the formation of $\mathrm{CO}_{2}$ in rumen liquor. For this reason a separate equation for silages should be developed. 


\section{REFERENCES}

Goerna, K. H. \& VaN Soest, P. J. (1970). Forage fiber analysis (apparatus, reagents, procedures, and some application). Agricultural Handbook, Agricultural Research Council. Washington, D.C.: USDepartment of Agriculture.

Menke, K. H. \& Ehrensvärd, U. (1974). Die Bestimmung der Stoffbilanz und die Berechnung der Stöchiometrie und der Energiebilanz bei der Vergärung von Pansensaft in vitro. Zeitschrift für Tierphysiologie, Tierernährung und Futtermittelkunde 34, 24-35.
Shiemane, R., Nehring, K., Hoffmann, L., Jentsch, W. \& Chudy, A. (1971). Energetische Futterbewertung und Energienormen. VEB Deutscher Landwirtschaftsverlag, Berlin, p. 75.

Searle, S. R. (1971). Linear Models, p. $130 \mathrm{ff}$. Now York, London: John Wiley.

Trluey, J. M. A. \& Terry, R. A. (1963). A two-stage method for the in vitro digestion of forage crops. Journal of the British Grassland Society 18, 104-111. 